\title{
Shifts in plant respiration and carbon use efficiency at a large-scale drought experiment in the eastern Amazon
}

\author{
D. B. Metcalfe ${ }^{1,9}$, P. Meir ${ }^{2}$, L. E. O. C. Aragão ${ }^{3}$, R. Lobo-do-Vale ${ }^{4}$, D. Galbraith ${ }^{1,2}$, R. A. Fisher ${ }^{5}$, \\ M. M. Chaves ${ }^{4}$, J. P. Maroco ${ }^{6}$, A. C. L. da Costa ${ }^{7}$, S. S. de Almeida ${ }^{8}$, A. P. Braga ${ }^{7}$, P. H. L. Gonçalves ${ }^{7}$, \\ J. de Athaydes ${ }^{7}$, M. da Costa $^{7}$, T. T. B. Portela ${ }^{7}$, A. A. R. de Oliveira ${ }^{7}$, Y. Malhi ${ }^{1}$ and M. Williams ${ }^{2}$ \\ ${ }^{1}$ Centre for the Environment, University of Oxford, Oxford, UK; ${ }^{2}$ School of Geosciences, University of Edinburgh, Edinburgh, UK; ${ }^{3}$ School of Geography, \\ University of Exeter, Exeter, UK; ${ }^{4}$ Instituto Superior de Agronomia, Universidade Tecnica de Lisboa, Lisbon, Portugal; ${ }^{5}$ Los Alamos National Laboratory, \\ Los Alamos, NM, USA; ${ }^{6}$ Instituto de Tecnologia Quimica e Biologica, Oeiras, Portugal; ${ }^{7}$ Centro de Geociências, Universidade Federal do Pará, Belem, \\ Brazil; ${ }^{8}$ Coordenação de Botânica, Museu Paraense Emilio Goeldi, Brazil; ${ }^{9}$ Present address: Department of Forest Ecology and Management, Swedish \\ University of Agricultural Sciences, Skogsmarksgränd, Umeå, Sweden
}

\section{Summary}

Author for correspondence: Daniel B. Metcalfe

Tel.: + 441865285182

Email: daniel.metcalfe@ouce.ox.ac.uk

Received: 15 February 2010

Accepted: 19 April 2010

New Phytologist (2010) 187: 608-621 doi: $10.1111 / j .1469-8137.2010 .03319 . x$

Key words: Amazon rain forest, carbon cycling, carbon dioxide, carbon use efficiency, drought, gross primary productivity, net primary productivity, partitioning.
- The effects of drought on the Amazon rainforest are potentially large but remain poorly understood. Here, carbon (C) cycling after 5 yr of a large-scale through-fall exclusion (TFE) experiment excluding about $50 \%$ of incident rainfall from an eastern Amazon rainforest was compared with a nearby control plot.

- Principal C stocks and fluxes were intensively measured in 2005. Additional minor components were either quantified in later site measurements or derived from the available literature.

- Total ecosystem respiration $\left(R_{\mathrm{eco}}\right)$ and total plant $\mathrm{C}$ expenditure (PCE, the sum of net primary productivity (NPP) and autotrophic respiration $\left(R_{\text {auto }}\right)$ ), were elevated on the TFE plot relative to the control. The increase in PCE and $R_{\text {eco }}$ was mainly caused by a rise in $R_{\text {auto }}$ from foliage and roots. Heterotrophic respiration did not differ substantially between plots. NPP was $2.4 \pm 1.4 \mathrm{t} \mathrm{C} \mathrm{ha}^{-1} \mathrm{yr}^{-1}$ lower on the TFE than the control. Ecosystem carbon use efficiency, the proportion of PCE invested in NPP, was lower in the TFE plot $(0.24 \pm 0.04)$ than in the control $(0.32 \pm 0.04)$.

- Drought caused by the TFE treatment appeared to drive fundamental shifts in ecosystem C cycling with potentially important consequences for long-term forest C storage.

\section{Introduction}

Tropical forests play a key role in global biogeochemical cycles and climate. The Amazon rainforest alone contains 70-120 billion tonnes of carbon (C) in vegetation, an amount of $\mathrm{C}$ equivalent to over a decade of global anthropogenic emissions (Houghton et al., 2001; Malhi et al., 2006; Saatchi et al., 2007). Recent analyses predict an increased probability of greater drought frequency and severity across the Amazon over the next $100 \mathrm{yr}$ because of climate change, regional deforestation and fire (Werth \& Avissar, 2002; Christensen et al., 2007; Cox et al., 2008; Harris et al., 2008; Malhi et al., 2008). The effects of drought upon ecosystem structure and function in the
Amazon are potentially large but remain poorly defined. Relatively little information from field studies is available to test whether the modelled representation of drought effects in the region - decreased forest photosynthesis and increased soil $\mathrm{CO}_{2}$ efflux (Tian et al., 1998; Peylin et al., 2005; Zeng et al., 2005) - is realistic. Model projections are constrained particularly by a lack of detailed knowledge about the physical controls upon ecosystem $\mathrm{C}$ partitioning and soil $\mathrm{CO}_{2}$ efflux. A range of studies from drought experiments in the Amazon have examined numerous $\mathrm{C}$ cycle components in isolation (Nepstad et al., 2002; Davidson et al., 2004, 2008; Sotta et al., 2007; Metcalfe et al., 2007a, 2008, 2010; Brando et al., 2008; da Silva et al., 2009; Meir et al., 2009; da Costa et al., 2010), but none have yet synthesized these 
individual components to construct a full $\mathrm{C}$ budget of a droughted Amazon forest.

The overall purpose of this study, therefore, was to examine the impacts of a large-scale through-fall exclusion (TFE) treatment in an eastern Amazon primary rainforest on ecosystem $\mathrm{C}$ cycling and partitioning. Our analysis here is centred on measurements made across one full seasonal cycle, $4 \mathrm{yr}$ after imposition of the TFE treatment, in 2005, comparing data from the TFE and a nearby control plot. While the TFE treatment was not replicated (Hurlbert, 1984, 2004), it provides insights into ecosystem processes that would otherwise have been impossible to capture in smaller-scale experiments (Carpenter, 1996; Sullivan, 1997; Osmond et al., 2004; Stokstad, 2005). On both plots, for the focal period of 2005, we estimated and integrated all key ecosystem $\mathrm{C}$ fluxes to measure forest net primary productivity (NPP) and ecosystem respiration $\left(R_{\text {eco }}\right)$ :

$R_{\text {eco }}=R_{\text {hetero }}+R_{\text {auto }}$

Eqn 1

where $R_{\text {hetero }}$ and $R_{\text {auto }}$ represent $R$ from heterotrophic and autotrophic sources, respectively. The total amount of $\mathrm{C}$ expended by trees at a stand scale (plant $\mathrm{C}$ expenditure, PCE) was estimated as:

$\mathrm{PCE}=\mathrm{NPP}+R_{\text {auto }}$

Eqn 2

Under steady-state conditions, where C inputs equal outputs, the following should hold true:

$\mathrm{GPP} \approx \mathrm{PCE} \approx R_{\mathrm{eco}}$

Eqn 3

where GPP (gross primary productivity) is the total quantity of $\mathrm{C}$ entering the forest via photosynthesis. We assessed whether this assumption was valid for both plots by comparing GPP estimated from a previous study, which applied a site-parameterized ecophysiological model to both plots (Fisher et al., 2007), with our estimates of plot-level PCE and $R_{\text {eco }}$. In the case of a substantial imbalance between tree GPP and PCE

$\mathrm{NTP}=\mathrm{PCE}-\mathrm{GPP}$

Eqn 4

We examined the implications for the net change in tree $\mathrm{C}$ balance (net tree production, NTP).

\section{Materials and Methods}

\section{Field site and experimental design}

The study site is located in the Caxiuana National Forest, Pará State, northeastern Brazil ( $\left.1^{\circ} 43^{\prime} 3.5^{\prime \prime} \mathrm{S}, 51^{\circ} 27^{\prime} 36^{\prime \prime} \mathrm{W}\right)$. The forest is a lowland terra firme rainforest with high annual rainfall $(2000-2500 \mathrm{~mm})$ and a pronounced dry season
(Table 1). Across the entire year, mean soil surface temperature is approximately $25^{\circ} \mathrm{C}$, with little seasonal and diurnal variation. The soil type is a highly weathered yellow Oxisol (Quesada et al., 2009). In January 2002, a 1 ha plot (TFE plot) was modified by the installation of plastic panels placed at 1-2 $\mathrm{m}$ above the ground, excluding approximately $50 \%$ of incident rainfall, and causing a shift in soil water availability, plant water relations, leaf physiology and, ultimately, tree growth and survival (Fig. 1). The change in annual rainfall magnitude and dry season length imposed by the TFE treatment simulated some key aspects of a precipitation regime more commonly encountered in some savannas and deciduous forests in the region (Betts et al., 2004; Malhi et al., 2009a), which is consistent with long-term climate predictions for the region from at least one major global climate model- HadCM3 (Collins et al., 2001).

Air temperature beneath the TFE panels was c. $2^{\circ} \mathrm{C}$ warmer than ambient air during the dry season, although soil temperature remained similar to ambient values throughout. During the wet season, air temperatures above and below the TFE panels were similar (da Costa et al., 2006). The boundary of the TFE plot was trenched to a depth of $1-2 \mathrm{~m}$ and lined with plastic to minimize lateral ingress of water from adjacent, wetter soil. The control plot perimeter was also trenched to avoid confounding treatment effects. All measurements were taken at least $10 \mathrm{~m}$ inside the perimeter of each plot to minimize edge effects.

\section{Above-ground carbon stocks and solid fluxes}

Canopy leaf area density and leaf morphology data were derived from Metcalfe et al. (2010). To calculate leaf area

Table 1 Key vegetation and soil features for each plot surveyed

\begin{tabular}{lcc}
\hline Plot characteristics & Control & TFE \\
\hline Vegetation & 532 & 501 \\
Tree number ha ${ }^{-1}$ & 118 & 113 \\
Tree species number & $2.7 \pm 0.2$ & $3.4 \pm 0.5$ \\
Surface litter mass $(\mathrm{t} \mathrm{C} \mathrm{ha-1)}$ & & \\
Soil 0-10 cm & 1.4 & 1.2 \\
Bulk density (t m $\left.{ }^{3}\right)$ & 18 & 13 \\
Clay content (\%) & 5 & 4 \\
Silt content $(\%)$ & 77 & 83 \\
Sand content (\%) & 4 & 4 \\
pH & 9 & 12 \\
Carbon concentration $\left(\mathrm{mg} \mathrm{g}^{-1}\right)$ & 0.4 & 0.3 \\
Nitrogen concentration $\left(\mathrm{mg} \mathrm{g}^{-1}\right)$ & 0.1 & 0.2 \\
Phosphorus concentration $\left(\mathrm{mg} \mathrm{g}^{-1}\right)$ & 23 & 35 \\
Carbon : nitrogen ratio & 0.8 & 0.7 \\
Soil cation exchange $\left(\mathrm{cmol} \mathrm{dm}^{-3}\right)$ & & \\
\hline
\end{tabular}

Values indicate mean $\pm 95 \%$ confidence intervals (where available and appropriate). Surface litter means are derived from 25 replicates. TFE, through-fall exclusion. Tree number and basal area represent all individuals over $10 \mathrm{~cm}$ diameter at breast height, measured in January 2005. Soil values are collated from data in Sotta et al. (2007). 


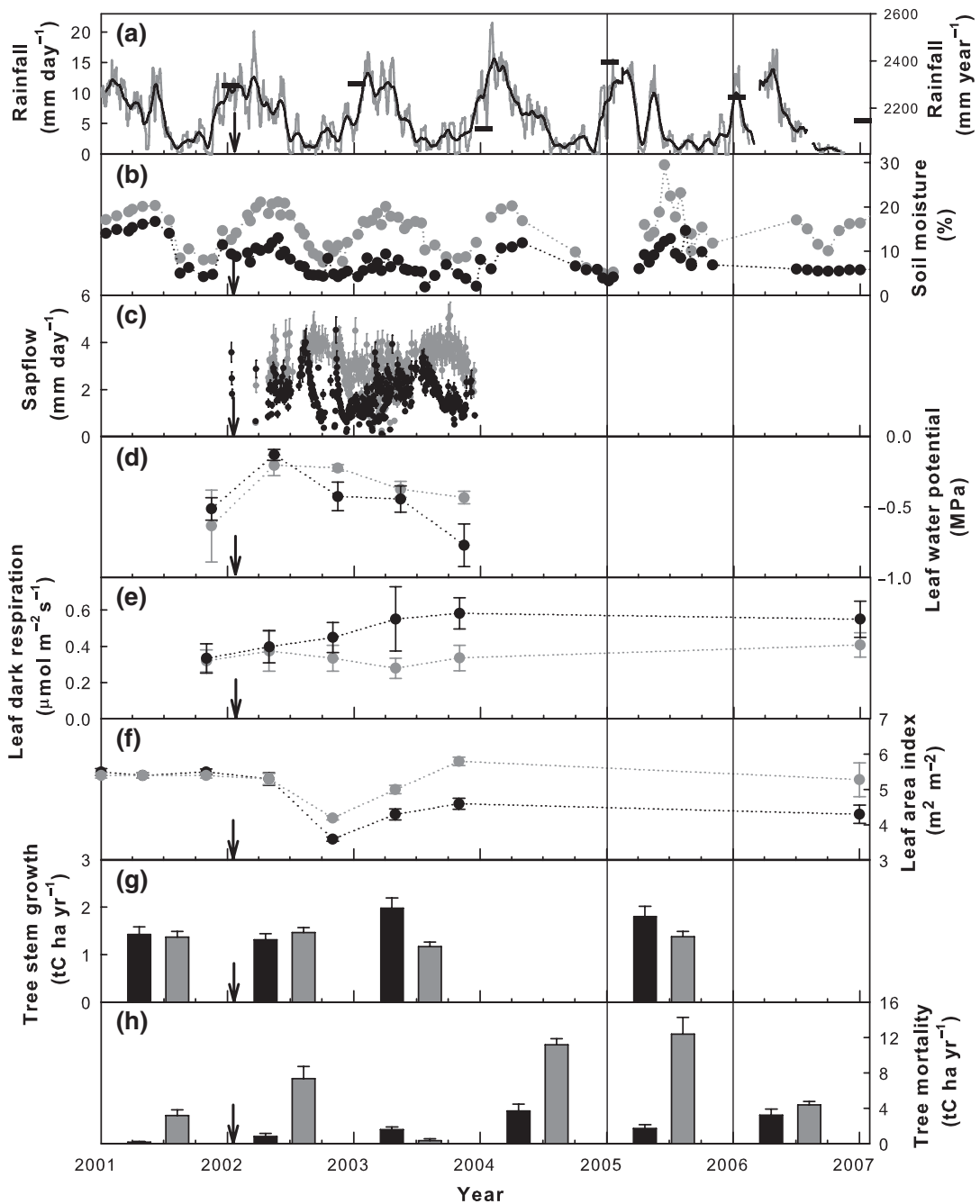

Fig. 1 Through-fall exclusion (TFE) effects on key forest processes before, during and after the study period of 2005 (highlighted). Grey circles and bars, control; closed circles and bars, through-fall exclusion. The arrow at the base of each panel indicates the beginning of the TFE treatment. (a) Rainfall is presented as daily totals (grey line), $30 \mathrm{~d}$ moving average (black line) and annual totals for the preceding year (black bars). (b) Soil volumetric moisture values before and after 2005 represent the mean of hourly measurements from time domain reflectometer probes (TDR) installed at 5,100 and $250 \mathrm{~cm}$ soil depths in a single soil pit on each plot. During 2005, soil moisture values are the mean of 25 TDR soil surface (30 cm soil depth) monthly measurements along a regularly spaced grid within each plot. (c) Sapflow and leaf water potential (d) data are derived from Fisher et al. (2006). Leaf dark respiration $(R)(\mathrm{e})$ and leaf area index (f) data are reproduced from Metcalfe et al. (2010). (g) Tree stem growth and mortality (h) estimates include only stems $>10 \mathrm{~cm}$ diameter at breast height $(\mathrm{DBH})$; these data are reproduced from da Costa et al. (2010). Error bars indicate 95\% confidence intervals around plot means. Given the unreplicated nature of the plots, error bars represent only within-plot spatial variation and measurement error rather than landscape scale heterogeneity. index (LAI, $\mathrm{m}^{2}$ leaf $\mathrm{m}^{-2}$ ground), images of the canopy were recorded at 25 locations within each plot in late 2004 and early 2007 with a digital camera and hemispherical lens; total LAI was apportioned into canopy height categories with LAI height profile data collected at a tower in the centre of each plot. Mean leaf mass per unit area (LMA) for each plot was calculated for the same periods by harvesting leaves from different canopy layers, determining area and dry mass of each leaf, then dividing dry mass by one-sided area. Values intermediate to those calculated on the two sampling dates were used to estimate LAI and LMA in 2005. To derive estimates of total plot foliar biomass, LAI and LMA from each canopy layer were multiplied and then the estimated foliar biomass for each layer was summed.

The monthly flux of litter falling from the canopy in 2005 was recorded in 20 mesh traps (area $=1 \mathrm{~m}^{2}$ per trap) placed at $1 \mathrm{~m}$ above the ground surface on the control plot, and above the plastic panels on the TFE plot (height 2$2.5 \mathrm{~m}$ ). Litter retrieved from the traps was dried at $70^{\circ} \mathrm{C}$ to constant mass, separated into leaves, flowers, fruits and seeds, woody material $<2 \mathrm{~cm}$ diameter and weighed. Previous studies have shown that $36-40 \%$ of litterfall is intercepted before it reaches litter traps and decomposed within the canopy (Edwards, 1977; Frangi \& Lugo, 1985), so we multiplied recorded litterfall by 1.3 to provide a conservative correction for this 'canopy storage' term. In addition, litterfall collection in mesh traps does not account for material lost via herbivory (12-30\% of canopy leaf mass, Clark et al., 2001). Therefore, we conservatively estimated mean herbivory on both plots as $10 \%$ of leaf litterfall.

Branches $>2 \mathrm{~cm}$ diameter falling from live trees were not adequately sampled by mesh traps and so this flux was separately monitored between December 2008 and August 2009 by collecting, drying at $70^{\circ} \mathrm{C}$ to constant mass and weighing all woody material $>2 \mathrm{~cm}$ diameter which appeared along four $1 \times 80 \mathrm{~m}$ transects per plot that had previously been cleared of all woody material (see the Ground carbon stocks and solid fluxes section).

Plot values for live and dead stem standing biomass, growth, recruitment and mortality were obtained from da 
Costa et al. (2010). Annual stem growth increment was recorded for all live tree stems $>10 \mathrm{~cm}$ diameter at breast height (DBH, $1.35 \mathrm{~m}$ ) between 2001 and 2008. Recruitment of new trees into the $>10 \mathrm{~cm} \mathrm{DBH}$ category was recorded in August 2005. Tree diameter was converted to mean ( $\pm 95 \%$ confidence intervals) above-ground stem mass using eight previously published allometric equations (da Costa et al., 2010). Mortality was assessed as death or disappearance of previously permanently marked stems.

In addition to stem mass loss via mortality, we included a term for mass loss via live tree damage (heartwood rot, crown and partial trunk loss) of $0.44 \pm 0.10 \mathrm{t} \mathrm{C} \mathrm{ha}^{-1} \mathrm{yr}^{-1}$ from Chambers et al. (2001). The biomass of smaller stems was estimated once in March 2005 by recording diameter of all stems between 2 and $10 \mathrm{~cm} \mathrm{DBH}$ in a $20 \times 20 \mathrm{~m}$ area on both plots, and using the same DBH-biomass conversion equations as for the larger stems using mean wood density for trees $>10 \mathrm{~cm} \mathrm{DBH}$ on each plot $\left(0.7 \mathrm{~g} \mathrm{~cm}^{-3}\right)$, and extrapolating this value to the rest of the plot area. The growth of stems between 2 and $10 \mathrm{~cm} \mathrm{DBH}$ was estimated by quantifying the proportion of growth to biomass for stems $>10 \mathrm{~cm} \mathrm{DBH}$, and multiplying this value by estimated plot biomass of stems between 2 and $10 \mathrm{~cm}$ $\mathrm{DBH}$. This method assumed that tree growth was similar across size classes, which was unlikely, but in the absence of direct measurements of the growth of stems $2-10 \mathrm{~cm} \mathrm{DBH}$ it yielded an approximation of this relatively minor component $(<1 \%$ of total NPP in our analysis).

\section{Ground carbon stocks and solid fluxes}

Coarse woody debris (CWD) necromass was calculated in December 2009 by removing and weighing in situ all woody material $>2 \mathrm{~cm}$ diameter along four $1 \times 80 \mathrm{~m}$ transects within each plot. A subset of this material was then dried at $70^{\circ} \mathrm{C}$ to constant mass and reweighed to derive a correction factor for the wet mass values from the rest of the material. Then each piece of the subset was measured with callipers to estimate surface area. The correlation between piece surface area $\left(\mathrm{cm}^{2}\right)$ and dry weight $(\mathrm{g})$ was used to estimate surface area of all pieces collected on the plots $\left(r^{2}=0.81\right.$, mass $=16.49 \times$ area $\left.^{0.63}\right)$. Finally, each piece from the subset was placed into a water-filled cylinder to measure piece volume, and hence tissue density (dry mass/volume). Density was estimated separately for five classes of wood decomposition following Harmon et al. (1995). In cases where material within the transect was too large to remove and weigh manually, the diameter at three points was recorded to estimate surface area and volume, and wood density associated with the decomposition class was used to convert the volume of each piece into mass. Total plot CWD mass and surface area were calculated as the sum of the smaller pieces removed from the transects and the larger pieces remaining on the transects. To backcalculate CWD biomass for 2005, our study period, we assumed that the rate of CWD accumulation necessary to achieve the observed 2009 plot difference was proportional to stem mortality, quantified annually by da Costa et al. (2010).

Ground surface fine litter mass (including woody material $<2 \mathrm{~cm}$ diameter) was collected from 25 areas $\left(0.25 \mathrm{~m}^{2}\right)$ in each plot in December 2009. Litter samples were cleaned of inorganic detritus, dried at $70^{\circ} \mathrm{C}$ to constant mass and weighed.

Fine root biomass and production data were derived from Metcalfe et al. (2008). Briefly, 27 soil cores down to $30 \mathrm{~cm}$ depth were removed from each plot in 2005, fine roots $(<2 \mathrm{~mm}$ diameter) were removed following the method of Metcalfe et al. (2007b), dried at $70^{\circ} \mathrm{C}$ to constant mass and then weighed. Fine roots below $30 \mathrm{~cm}$ and coarse roots (> $2 \mathrm{~mm}$ diameter) were not sampled with these cores. To correct for this, four $1.5 \times 1.5 \mathrm{~m}$ holes were excavated to $3 \mathrm{~m}$ soil depth in each plot in June 2008. All roots retrieved were collected, dried at $70^{\circ} \mathrm{C}$ to constant mass and weighed. Dry root mass was apportioned into soil depth and diameter categories. From these data (D Galbraith, unpublished), the proportions of fine root mass through the entire soil column down to $3 \mathrm{~m}$ soil depth located within the surface (control $=0.63, \mathrm{TFE}=0.65$ ), and of total root mass represented by roots $<2 \mathrm{~mm}$ diameter (control $=0.08, \mathrm{TFE}=0.49$ ), were calculated and applied to the measured surface fine root values to estimate total root mass and production down to $3 \mathrm{~m}$ soil depth and for all root diameters. Because of the low sample size in this study, we applied error estimates of $13 \%$ around coarse root standing biomass and growth values from a more extensive sampling programme in a similar forest (Silver et al., 2000). To back-calculate coarse root biomass for 2005, our main period of interest, we assumed that the rate of coarse root mortality necessary to achieve the observed difference between plots in 2008 was proportional to the measured rate of stem mortality (da Costa et al., 2010). To quantify coarse root growth, the proportion of growth to biomass of stems $>10 \mathrm{~cm}$ DBH was quantified, and this value was multiplied by the estimated plot biomass of coarse roots, down to $3 \mathrm{~m}$ soil depth. This method assumed that coarse root growth and stem growth were similar and that coarse root growth was constant down the soil profile. This was a source of uncertainty but in the absence of direct measurements of coarse root growth anywhere in the soil profile and fine root growth below $30 \mathrm{~cm}$ soil depth it yielded an approximation of this relatively minor component $(<11 \%$ of total NPP in our analysis).

Net dissolved organic carbon (DOC) export (DOC runoff - DOC deposition) was taken as $0.19 \pm 0.07 \mathrm{t} \mathrm{C}$ $\mathrm{ha}^{-1} \mathrm{yr}^{-1}$ from an intensive study of DOC dynamics in a central Amazon catchment (Waterloo et al., 2006). 


\section{Carbon dioxide efflux}

Leaf area index and leaf dark $R$ data were derived from Metcalfe et al. (2010). Leaf dark $R$ was recorded from leaves throughout the canopy in 2003 and 2007. All measurement campaigns sampled fully expanded, nonsenescent, undiseased leaves. Leaf dark $R$ was recorded after $\mathrm{CO}_{2}$ gas exchange in dark conditions had stabilized (usually after c. $10 \mathrm{~min}$ ), at ambient air $\mathrm{CO}_{2}$ concentration (360-380 ppm) and humidity (60-80\%). Estimates of leaf dark $R$ per unit leaf area in each canopy layer was multiplied by mean plot LAI located within the same canopy layer, and then all layers were summed to derive plot-level estimates of night-time leaf $R$ assuming $12 \mathrm{~h}$ of darkness each day throughout the year and a constant temperature of $25^{\circ} \mathrm{C}$ (Metcalfe et al., 2010). Values for 2005 were estimated as the mean of the measurements in November 2003 and January 2007. Leaf light $R$ on both plots was estimated as $67 \%$ of leaf dark $R$ from Lloyd et al. (2009), who used light response curves from another lowland Amazon forest (Domingues et al., 2005) and applied light-inhibition equations from eucalyptus seedlings (Atkin et al., 2000).

Emissions of volatile organic compounds (VOCs) constitute another minor source of $\mathrm{C}$ from leaves. We used a value of $0.13 \pm 0.05 \mathrm{t} \mathrm{C} \mathrm{ha}^{-1} \mathrm{yr}^{-1}$ for this component (Malhi et al., 2009b) which sums published estimates of VOC, including isoprene and terpene (Kuhn et al., 2007), and methane (do Carmo et al., 2006) emissions from tropical forests.

No site measurements of live tree stem $R$ at $1.3 \mathrm{~m}$ were available, so a value of $0.6 \pm 0.08 \mu \mathrm{mol} \mathrm{m}{ }^{-2}$ stem surface $s^{-1}$ was taken from the existing literature (Nepstad et al., 2002; Meir \& Grace, 2002) and applied to both plots. This may underestimate total stem $R$ rates since portions of stem higher up (Yoda, 1983) and branches (Cavaleri et al., 2006) tend to have higher $\mathrm{CO}_{2}$ effluxes than the main bole near the ground. Tree stem area was estimated using a taper function to estimate stem basal diameter for all trees $>2 \mathrm{~cm} \mathrm{DBH}$ on both plots (Chambers et al., 2000) and then applying an equation relating basal diameter to total stem surface area (Yoneda, 1993) from 315 terra firme Amazon trees (Chambers et al., 2004). Plot-level scale stem C efflux was estimated by multiplying $R_{\text {stem }}$ per unit stem area by total plot live stem area.

Soil $\mathrm{CO}_{2}$ efflux data were derived from Metcalfe et al. (2007a). Total soil $\mathrm{CO}_{2}$ efflux $\left(R_{\text {soil }}\right)$ was recorded each month through 2005 at 25 points in each plot. $R_{\text {soil }}$ was partitioned into contributions from surface organic litter, roots and soil organic matter at nine points on each plot in the dry (November 2004) and wet (June 2005) seasons. Monthly contributions from each of the $R_{\text {soil }}$ components were linearly interpolated between these two periods.

$R$ from coarse woody debris was recorded once in August 2009 from 12 to 16 pieces of dead wood on the ground for each of the five decomposition classes (see the Ground carbon stocks and solid fluxes section for details of the
CWD necromass survey) randomly selected on the control and TFE plots. We included the $R$ contribution from standing dead trees using the same surface area estimation methodology as live stems, and assuming they had similar $\mathrm{CO}_{2}$ efflux rates to ground CWD, which was a source of uncertainty but in the absence of detailed information about wood decomposition patterns in the tropics it yielded an approximation of this relatively minor component (< $11 \%$ of total $R$ in our analysis). Plot-level dead wood $R$ was estimated by multiplying stem $R$ per unit dead wood area by total plot dead wood surface area.

\section{Data analysis and presentation}

The lack of treatment replication precluded fully comparative statistical analysis (Hurlbert, 1984, 2004), but 95\% confidence intervals were calculated around means as an indication of the reliability of the observed mean differences at a plot scale. Throughout the manuscript, therefore, error bars represent only within-plot spatial variation and measurement error rather than landscape-scale heterogeneity. Errors were propagated by quadrature of absolute errors for addition and subtraction, and quadrature of relative errors for division and multiplication (Aragão et al., 2009). This assumes that the errors are independent and normally distributed. All $R$ terms were summed into $R_{\text {auto }}$ and $R_{\text {hetero }}$ contributions, which together make up $R_{\text {eco. }}$. Total NPP was calculated as the sum of all plant growth components, and PCE was then estimated as the sum of total NPP and $R_{\text {auto }}$. Carbon use efficiency (CUE) at an ecosystem level and individually for different plant components (canopy, stems, roots) was calculated as:

$\mathrm{CUE}=\frac{\mathrm{NPP}}{\mathrm{NPP}+R_{\text {auto }}}$

Eqn 5

Turnover time (1/turnover rate) estimates for specific components on the control plot were derived by dividing $\mathrm{C}$ fluxes by stocks. Independent checks on $\mathrm{C}$ flux estimates were derived from eddy covariance (Carswell et al., 2002) and detailed modelling studies (Fisher et al., 2007) at the site, albeit for different time periods from the current study. In addition, data were compared to published equations, which use a mass balance approach assuming steady-state conditions, to estimate total below-ground allocation (TBCA; equations from Raich \& Nadelhoffer (1989) were modified to include contributions from coarse wood, root litter and DOC) and soil $\mathrm{CO}_{2}$ efflux (Malhi et al., 2009b)

\section{Results}

\section{Ecosystem C balance, partitioning and CUE}

Estimated PCE during the period of measurement was slightly greater in the TFE $\left(33.9 \pm 3.6 \mathrm{tC} \mathrm{ha}^{-1} \mathrm{yr}^{-1}\right)$ than in the 


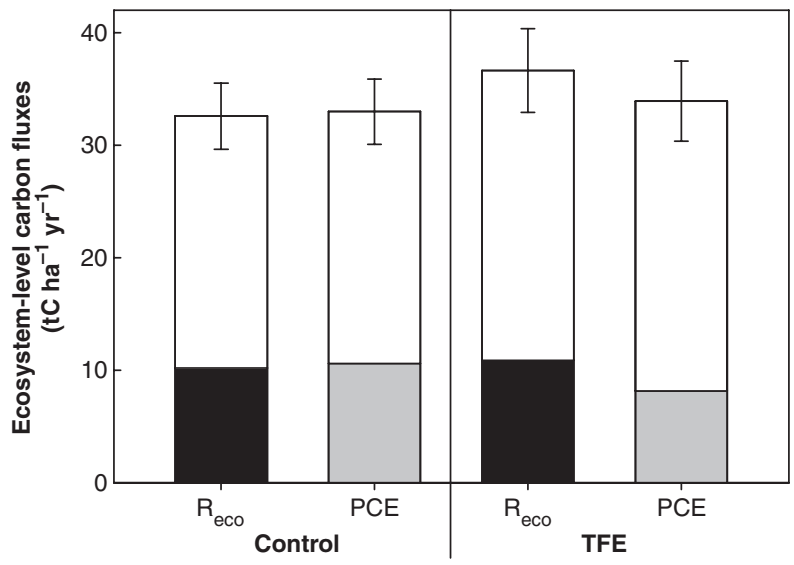

Fig. 2 Total ecosystem-level carbon fluxes on the plots. Grey bars, net primary productivity (NPP); open bars, autotrophic respiration $\left(R_{\text {auto }}\right)$; closed bars, heterotrophic respiration $\left(R_{\text {hetero }}\right)$. All data and their sources are specified in Table 2. Error bars indicate 95\% confidence intervals around the total flux values. Given the unreplicated nature of the plots, error bars represent only within-plot spatial variation and measurement error rather than landscape-scale heterogeneity. $R_{\text {eco, }}$ ecosystem respiration; TFE, through-fall exclusion; PCE, plant carbon expenditure.

control plot $\left(33.0 \pm 2.9 \mathrm{t} \mathrm{C} \mathrm{ha}^{-1} \mathrm{yr}^{-1}\right)$ (Table 2, Fig. 2). $R_{\text {eco }}$ was elevated on the TFE plot compared with the control plot, although there was substantial uncertainty around the plot means (Table 2, Fig. 2; $36.6 \pm 3.7$ and $32.6 \pm 2.9$ t C $\mathrm{ha}^{-1} \mathrm{yr}^{-1}$, respectively). Greater $R_{\text {eco }}$ in the TFE plot was mainly attributable to the higher $R_{\text {auto }}$ flux of $25.8 \pm 3.4 \mathrm{t} \mathrm{C} \mathrm{ha}^{-1} \mathrm{yr}^{-1}$ compared with $22.4 \pm 2.8 \mathrm{t} \mathrm{C}$ $\mathrm{ha}^{-1} \mathrm{yr}^{-1}$ in the control (Table 2, Fig. 2), which in turn was driven by a rise in canopy and root $R$ (Table 2 , Fig. 3b). By contrast, $R_{\text {hetero }}$ was similar between plots $\left(c .10 .5 \mathrm{t} \mathrm{C} \mathrm{ha}^{-1} \mathrm{yr}^{-1}\right)$ because greater estimated TFE dead wood $R$ was offset by lower soil heterotrophic $\mathrm{CO}_{2}$ efflux (Table 2, Fig. 3b).

Total estimated NPP was $2.4 \pm 1.4 \mathrm{t} \mathrm{C} \mathrm{ha}^{-1} \mathrm{yr}^{-1}$ lower on the TFE plot relative to the control (Table 2, Fig. 3a). On both plots, approximately half of NPP was derived from the canopy, with the remainder split evenly between roots and stems (Table 2, Fig. 3a). The trees on both plots allocated slightly more total assimilated C (NPP and $R_{\text {auto }}$ ) to the canopy (c. 38\%) than stems (c.33\%) or roots (c. 28\%), of which $70-80 \%$ was comprised of $R_{\text {auto }}$ for every component (Table 2). On both plots, canopy CUE was higher than either stem or root CUE (Fig. 4). The TFE treatment was associated with a lower CUE in all plant organs, but particularly canopy CUE (control, $0.41 \pm 0.07$; TFE, $0.30 \pm 0.07$ ). The overall effect was a lower ecosystem CUE in the TFE plot of $0.24 \pm 0.04$ compared with $0.32 \pm 0.04$ in the control plot (Table 2, Fig. 4).

\section{Quantities and dynamics of $\mathrm{C}$ stocks}

The ratio of below to above-ground live plant $\mathrm{C}$ stocks was $0.64 \pm 0.21$ in the control plot compared with $0.15 \pm 0.05$

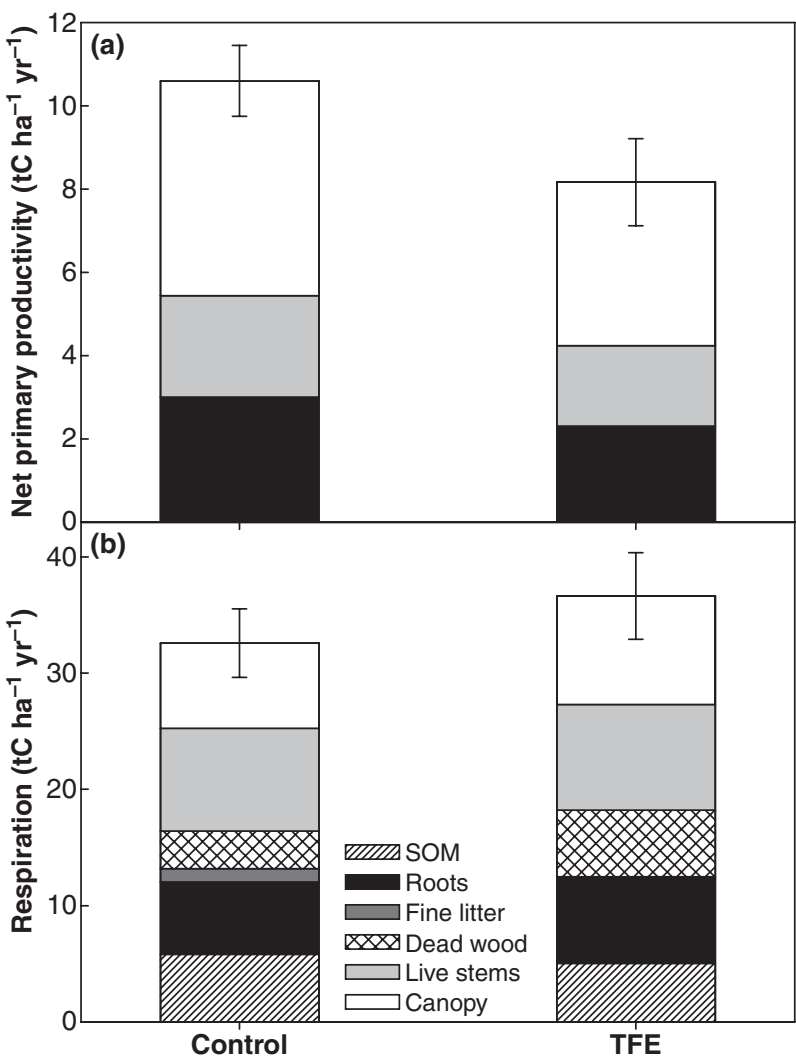

Fig. 3 Net primary productivity (NPP) (a) and respiration (R) (b) from different above- and below-ground ecosystem components on both plots. All data and their sources are specified in Table 2. Error bars indicate $95 \%$ confidence intervals around the total flux values. Given the unreplicated nature of the plots, error bars represent only within-plot spatial variation and measurement error rather than landscape-scale heterogeneity. Foliage $R$ incorporates measured leaf dark $R$ (Metcalfe et al., 2010) and modelled leaf light $R$ (Lloyd et al., 2009); stem $R$ is from all stems $>2 \mathrm{~cm}$ diameter at breast height assuming the same value of $R$ per unit stem surface area on both plots derived from the existing literature (Meir \& Grace, 2002; Nepstad et al., 2002), while dead wood $R$ includes contributions from coarse woody debris (CWD) on the ground and standing dead stems. Dead wood $R$ was measured in 2009 and back-calculated to 2005 assuming dead stem and CWD stock accumulation was proportional to measured tree mortality. Canopy production incorporates measured litterfall and literature-based estimates for herbivory, canopy storage of litter and volatile organic carbon emissions. Stem NPP values are derived from da Costa et al. (2010) and include growth of all stems $>2 \mathrm{~cm}$ diameter at breast height, branch fall and recruitment. Root growth includes both fine and coarse root growth down to $3 \mathrm{~m}$ soil depth using root profile data from D Galbraith (unpublished). TFE, through-fall exclusion; SOM, soil organic matter.

in the TFE plot (Fig. 5). In the control plot, estimated mean turnover time of live canopy foliage, fine litter on the ground, CWD, fine roots and live stems were 0.5, 0.7, 4.4, 3.4 and $88.0 \mathrm{yr}$, respectively (Fig. 6). Stocks of $\mathrm{C}$ in ground fine litter were slightly elevated in the TFE plot (Table $1, c$. $\left.0.7 \mathrm{t} \mathrm{C} \mathrm{ha}^{-1} \mathrm{yr}^{-1}\right)$, despite lower influx from canopy 


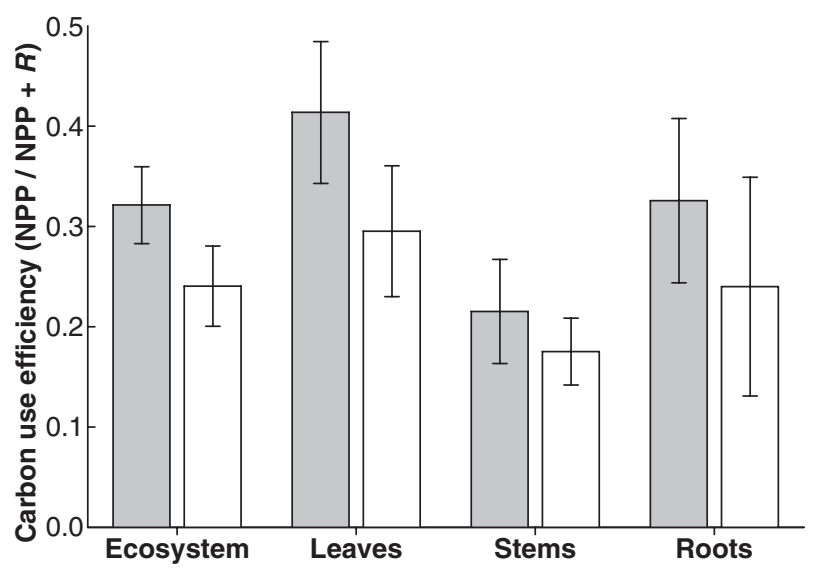

Fig. 4 Carbon use efficiency (CUE) at the ecosystem level and for different above- and below-ground plant components on both plots. Grey bars, control; open bars, through-fall exclusion. All data and their sources are specified in Table 2. Error bars indicate 95\% confidence intervals around the mean CUE values. Given the unreplicated nature of the plots, error bars represent only within-plot spatial variation and measurement error rather than landscape-scale heterogeneity. NPP, net primary productivity; $R$, respiration.

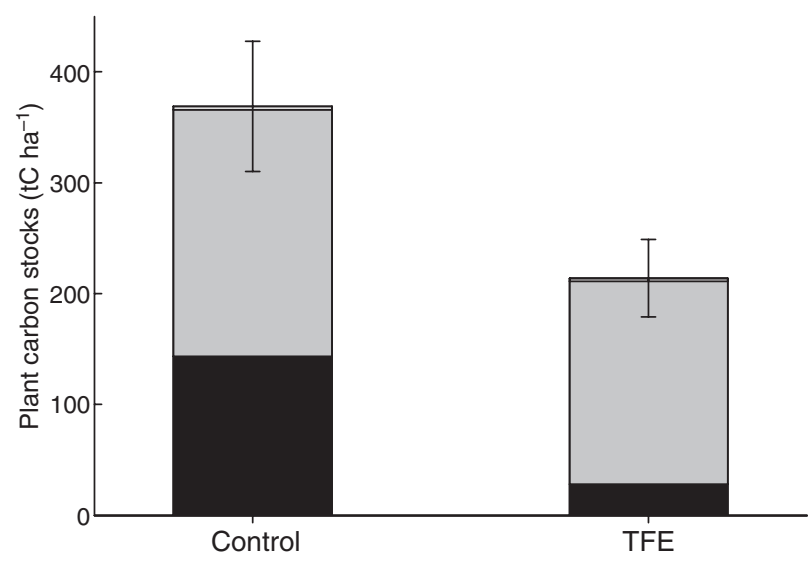

Fig. 5 Stocks of carbon in different above- and below-ground plant components on both plots. Open bars, canopy; grey bars, stems; closed bars, roots. Error bars indicate $95 \%$ confidence intervals around the total stocks. Given the unreplicated nature of the plots, error bars represent only within-plot spatial variation and measurement error rather than landscape-scale heterogeneity. Root stocks are presented down to $3 \mathrm{~m}$ soil depth using root profile data from $D$ Galbraith (unpublished). TFE, through-fall exclusion.

litterfall (Table 2, Fig. 3a; $0.9 \pm 0.2 \mathrm{t} \mathrm{C} \mathrm{ha}^{-1} \mathrm{yr}^{-1}$ ) compared with the control. In the TFE plot, microbial fine litter $R$ removed only around $4 \%$ of ground fine litter $\mathrm{C}$ stock each year (Tables 1,2$)$, which means that to balance $C$ inputs from litterfall whilst accounting for the observed increase in ground litter $\mathrm{C}$ stock relative to the control, $75 \pm 6 \%$ of the TFE fine litter stock must annually been removed by processes other than microbial $R$ (Fig. 7), such as physical disintegration and/or consumption by detritivores. Using the same approach, a greater percentage of the control plot standing surface litter $\mathrm{C}$ stock was removed each year via both microbial $R(43 \pm 4 \%)$ and other processes $(95 \pm 11 \%$; Fig. 7$)$. In the control plot, the annual decomposition metrics for ground litter exceeded 100\% because turnover time was $<1$ yr (Fig. 6).

\section{Quantities and dynamics of $\mathrm{CO}_{2}$ fluxes}

Plot differences in $\mathrm{CO}_{2}$ efflux were the net product of shifts in both $R$ per unit area of plant material (e.g. leaves, CWD), and the total amount of plant material area. These two properties often responded in different ways to the TFE treatment. For example, across all measurement periods, mean dark leaf $R$ per unit leaf area was greater in the TFE plot $\left(0.51 \pm 0.05 \mu \mathrm{mol} \mathrm{m}^{-2} \mathrm{~s}^{-1}\right)$ than in the control plot $\left(0.34 \pm 0.03 \mu \mathrm{mol} \mathrm{m}^{-2} \mathrm{~s}^{-1}\right)$, while LAI declined over $7 \mathrm{yr}$ following the imposition of the TFE treatment by $c$. $1 \mathrm{~m}^{2} \mathrm{~m}^{-2}$ relative to the control (Metcalfe et al., 2010). The net product of these interacting factors was a marked increase in plot-level dark leaf $R$ (Table 2, Fig. 3b; Metcalfe et al., 2010) in the TFE plot $\left(5.6 \pm 2.4 \mathrm{t} \mathrm{C} \mathrm{ha}^{-1} \mathrm{yr}^{-1}\right)$ relative to the control $\left(4.4 \pm 1.7 \mathrm{t} \mathrm{C} \mathrm{ha}^{-1} \mathrm{yr}^{-1}\right)$.

Total dead wood surface areas were $0.19 \pm 0.05$ and $0.27 \pm 0.06 \mathrm{~m}^{2} \mathrm{~m}^{-2}$ in the control and TFE plots, respectively. In both plots, $c .70 \%$ of dead wood area was in the form of standing stems with the remainder comprising ground CWD. The mean CWD $R$ values per unit wood area were $4.6 \pm 0.9$ and $5.5 \pm 1.6 \mu \mathrm{mol} \mathrm{m} \mathrm{m}^{-2} \mathrm{~s}^{-1}$ in the control and TFE plots, respectively. The weak trend towards higher mean CWD $R$ on the TFE plot was specifically attributable to the greater quantity of relatively undecomposed CWD in the TFE plot (Fig. 8b), possibly from a greater recent input of new wood via increased tree mortality and branch fall, which appeared to have a higher rate of $R$ (Fig. 8a). The combination of a greater quantity of fresh, undecomposed CWD in the TFE plot and elevated rates of $R$ per unit area of fresh CWD translated into total CWD $R$ of $5.7 \pm 1.5 \mathrm{t} \mathrm{C} \mathrm{ha}^{-1} \mathrm{yr}^{-1}$ in the TFE plot compared with $3.3 \pm 0.9 \mathrm{t} \mathrm{C} \mathrm{ha}^{-1} \mathrm{yr}^{-1}$ in the control (Table 2, Fig. 3b).

Estimated plot-level stem $R$ emissions (Table 2, Fig. 3b) were similar in the TFE $\left(9.1 \pm 1.8 \mathrm{t} \mathrm{Cha}^{-1} \mathrm{yr}^{-1}\right)$ and control plots $\left(8.8 \pm 1.8 \mathrm{t} \mathrm{C} \mathrm{ha}^{-1} \mathrm{yr}^{-1}\right)$ because the lower stem area of trees $>10 \mathrm{~cm} \mathrm{DBH}$ in the TFE plot was outweighed by the higher stem area of trees between 2 and $10 \mathrm{~cm} \mathrm{DBH}$.

$R_{\text {soil }}$, the sum of fine litter, root and soil organic matter respiration, was only slightly diminished by $0.69 \pm$ $0.14 \mathrm{t} \mathrm{C} \mathrm{ha}^{-1} \mathrm{yr}^{-1}$ in the TFE plot relative to the control during the measurement year of 2005 (Table 2, Fig. 3b; Metcalfe et al., 2007a). The relative contribution of autotrophic and heterotrophic sources to $R_{\text {soil }}$ differed between plots. Thus, in the control plot, $R_{\text {soil }}$ was divided almost equally between heterotrophic $\left(53 \%, 6.9 \pm 0.3 \mathrm{t} \mathrm{C} \mathrm{ha}^{-1} \mathrm{yr}^{-1}\right)$ and autotrophic $\left(47 \%, 6.2 \pm 0.3 \mathrm{tC} \mathrm{ha}^{-1} \mathrm{yr}^{-1}\right)$ contributions, 
New

Fig. 6 Turnover time of different ecosystem components on the control plot. Turnover is calculated assuming steady-state conditions as input or output/stock. Error bars indicate 95\% confidence intervals around the mean turnover time values. Given the unreplicated nature of the plots, error bars represent only within-plot spatial variation and measurement error rather than landscape-scale heterogeneity. CWD, coarse woody debris.

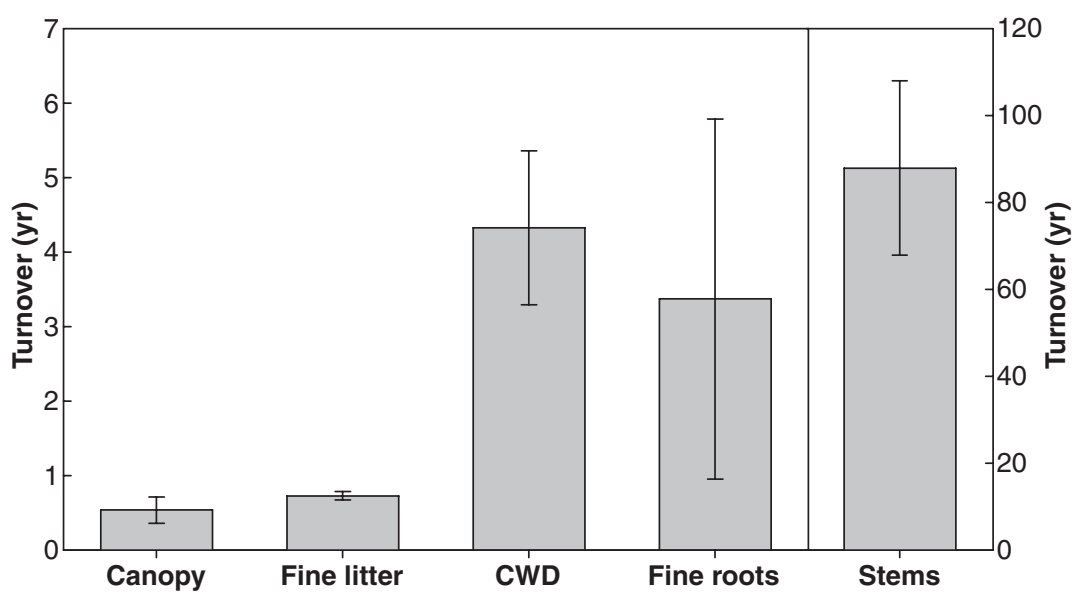

whereas $R_{\text {soil }}$ in the TFE plot was dominated to a greater extent by autotrophic sources $\left(59 \%, 7.3 \pm 0.3 \mathrm{t} \mathrm{C} \mathrm{ha}^{-1} \mathrm{yr}^{-1}\right)$ and heterotrophic $R\left(41 \%, 5.1 \pm 0.2 \mathrm{t} \mathrm{C} \mathrm{ha}^{-1} \mathrm{yr}^{-1}\right)$ contributed relatively less (Table 2, Fig. 3b). Expected $R_{\text {soil }}$ and TBCA, calculated for the control plot from $\mathrm{C}$ inputs and assuming steady-state conditions, were both lower than our measurements (Table 2).

\section{Discussion}

\section{Drought effects on net carbon fluxes: patterns and processes}

A key assumption of the multi-component integration 'bottom-up' approach employed here to examine $\mathrm{C}$ cycling at an eastern Amazon rainforest, is that steady state conditions exist at the site, and therefore that PCE is approximately equal to GPP. In the control plot, where steady-state conditions are plausible (at least over the timescale of the experiment), PCE estimated for the year of 2005 for this study $(33.0 \pm$ $2.9 \mathrm{t} \mathrm{C} \mathrm{ha}^{-1} \mathrm{yr}^{-1}$ ) was quite similar to estimates of GPP over 2002 and 2003 made using an ecophysiological model parameterized at the two plots (c. $30 \mathrm{t} \mathrm{C} \mathrm{ha}^{-1} \mathrm{yr}^{-1}$; Table 2; Fisher et al., 2007). By contrast, PCE in the TFE plot $\left(33.9 \pm 3.6 \mathrm{t} \mathrm{C} \mathrm{ha}^{-1} \mathrm{yr}^{-1}\right)$ was higher than the modelled GPP in the TFE plot of 26.9 and $27.1 \mathrm{t} \mathrm{C} \mathrm{ha}^{-1} \mathrm{yr}^{-1}$ in 2002 and 2003, respectively (Table 2; Fisher et al., 2007). As a preliminary exploration of the possible consequences of this mismatch between PCE and GPP in the TFE plot, we conducted the following analysis. We calculated the mean of the two annual modelled GPP estimates from the TFE plot and, assuming these estimates were representative of the forest in 2005 and had an uncertainty of 10\% (Fox et al., 2009), we then subtracted this GPP value from measured PCE for 2005. The result implies that the TFE forest was expending $7.0 \pm 4.5 \mathrm{t} \mathrm{C} \mathrm{ha}^{-1} \mathrm{yr}^{-1}$ more than it was assimilating (net tree production; Table 2). Clearly, a major uncertainty with this analysis is the assumption that modelled 2002 and 2003 GPP values are representative of conditions in 2005
- although, if anything, stand-level GPP values would be expected to decline further after 2003, and preliminary runs of the site-parameterized ecophysiological model beyond 2003 support this view (R Fisher, pers. comm.), which would suggest that the discrepancy between 2005 GPP and $\mathrm{PCE} / R_{\text {eco }}$ was likely to be even larger. Useful future lines of enquiry would be to quantify the sources of uncertainty that could not be incorporated into this analysis (e.g. TFE effects on stem allometry, stem $R$, leaf light $R$, herbivory, canopy litter storage, leaf temperature) to test this hypothesis further.

Notwithstanding the uncertainty surrounding this analysis, the substantial apparent 'overspend' of $\mathrm{C}$ by the forest could feasibly be sourced from nonstructural carbohydrate (NSC) stores and reductions in NPP. From the available literature, we estimate that the TFE forest may have had $c$. $20 \mathrm{t} \mathrm{C} \mathrm{ha}^{-1}$ of available NSC (c. $8 \%$ of live biomass; Graham et al., 2003; Würth et al., 2005; Poorter \& Kitajima, 2007) to draw upon at the beginning of the TFE treatment. In addition, during the treatment, the TFE forest would be making annual savings from lower NPP construction (25\% of biomass; Penning de Vries, 1975) and maintenance $R$ costs on the order of $3 \mathrm{t} \mathrm{C} \mathrm{ha}^{-1} \mathrm{yr}^{-1}$ (data not shown).

Previous work at the study site has indicated that the larger canopy trees responded isohydrically to drought, by maintaining leaf water potential above a minimum critical value to avoid xylem embolism, but thereby also reducing $\mathrm{C}$ assimilation rates (Fisher et al., 2006). This 'C starvation' hypothesis (McDowell et al., 2008; McDowell \& Sevanto, 2010) could provide one potential mechanistic explanation for the observed increase in tree mortality on the TFE plot (da Costa et al., 2010) and decline in reproduction (DB Metcalfe, unpublished). Our estimate of a large possible C overspend relative to likely NSC reserves is consistent with a scenario whereby trees may reach critically low amounts of NSC under extended drought conditions, and contrary to previous suggestions that large NSC pool sizes in forest trees render $\mathrm{C}$ starvation-induced mortality unlikely (Sala et al., 2010). An obvious next step is to verify whether trees 
Table 2 Summary of plot carbon fluxes

\begin{tabular}{|c|c|c|c|c|c|c|}
\hline \multirow[b]{2}{*}{ No. } & \multirow[b]{2}{*}{ Component } & \multicolumn{2}{|c|}{ Control plot } & \multicolumn{2}{|c|}{ TFE plot } & \multirow[b]{2}{*}{ Source } \\
\hline & & Mean & $95 \% \mathrm{Cl}$ & Mean & $95 \% \mathrm{Cl}$ & \\
\hline \multicolumn{7}{|c|}{ Net primary productivity (NPP, t C ha $\mathrm{har}^{-1}$ ) } \\
\hline 1 & Leaves & 2.5 & 0.1 & 2.1 & 0.1 & This study \\
\hline 2 & Twigs & 0.6 & 0.1 & 0.5 & 0.1 & This study \\
\hline 3 & Reproduction & 0.5 & 0.1 & 0.2 & 0.1 & This study \\
\hline 4 & Herbivory & 0.3 & 0.01 & 0.2 & 0.01 & Clark et al. (2001) \\
\hline 5 & Canopy storage & 1.1 & 0.1 & 0.8 & 0.04 & Edwards (1977) \\
\hline 6 & Branch & 0.5 & 0.4 & 0.4 & 0.1 & This study \\
\hline 7 & Stem $>10 \mathrm{~cm} \mathrm{DBH}$ & 1.8 & 0.2 & 1.4 & 0.1 & da Costa et al. (2010) \\
\hline 8 & Stem 2-10 cm DBH & 0.1 & 0.02 & 0.1 & 0.02 & This study \\
\hline 9 & Recruitment & 0.1 & 0.02 & 0.1 & 0.02 & This study \\
\hline 10 & Fine root & 1.7 & 0.6 & 2.0 & 1.0 & Metcalfe et al. (2008) \\
\hline 11 & Coarse root & 1.1 & 0.4 & 0.2 & 0.1 & This study \\
\hline 12 & Dissolved organic carbon & 0.2 & 0.07 & 0.2 & 0.07 & Waterloo et al. (2006) \\
\hline 13 & Volatile organic compounds & 0.1 & 0.05 & 0.1 & 0.05 & Malhi et al. (2009b) \\
\hline \multicolumn{7}{|c|}{ Respiration $\left(R, \mathrm{t} C \mathrm{ha}^{-1} \mathrm{yr}^{-1}\right)$} \\
\hline 14 & Dark leaf & 4.4 & 1.7 & 5.6 & 2.4 & Metcalfe et al. (2010) \\
\hline 15 & Light leaf & 2.9 & 1.1 & 3.8 & 1.6 & Lloyd et al. (2009) \\
\hline 16 & Live stems $>10 \mathrm{~cm} \mathrm{DBH}$ & 7.7 & 1.8 & 7.4 & 1.7 & da Costa et al. (2010) \\
\hline 17 & Live stems $2-10 \mathrm{~cm} \mathrm{DBH}$ & 1.2 & 0.3 & 1.7 & 0.4 & This study \\
\hline 18 & Dead stems & 2.5 & 0.7 & 3.9 & 1.3 & This study \\
\hline 19 & Coarse woody debris & 0.8 & 0.6 & 1.9 & 0.7 & This study \\
\hline 20 & Fine litter & 1.1 & 0.1 & 0.1 & 0.005 & Metcalfe et al. (2007a) \\
\hline 21 & Roots & 6.2 & 0.3 & 7.3 & 0.3 & Metcalfe et al. (2007a) \\
\hline 22 & Soil organic matter & 5.8 & 0.3 & 5.0 & 0.2 & Metcalfe et al. (2007a) \\
\hline \multicolumn{7}{|c|}{ Measured ecosystem level fluxes ( $\mathrm{C} \mathrm{ha}^{-1} \mathrm{yr}^{-1}$ ) } \\
\hline 23 & Total NPP & 10.6 & 0.9 & 8.2 & 1.0 & $\sum 1-13$ \\
\hline 24 & $R_{\text {eco }}$ & 32.6 & 2.9 & 36.6 & 3.7 & $\sum 14-22$ \\
\hline 25 & $R_{\text {auto }}$ & 22.4 & 2.8 & 25.8 & 3.4 & $\sum 14-17,21$ \\
\hline 26 & $R_{\text {hetero }}$ & 10.2 & 1.0 & 10.9 & 1.5 & $\sum 18-20,22$ \\
\hline 27 & PCE & 33.0 & 2.9 & 33.9 & 3.6 & $23+25$ \\
\hline 28 & NTPa & 1.8 & 4.3 & 7.0 & 4.5 & $27-$ mean of $(31+32)$ \\
\hline 29 & TBCA & 9.2 & 0.8 & 9.6 & 1.1 & $\sum 10-12,21$ \\
\hline 30 & Ecosystem CUE & 0.32 & 0.04 & 0.24 & 0.04 & $23 /(23+25)$ \\
\hline \multicolumn{7}{|c|}{ Alternative ecosystem level fluxes ( $\mathrm{C} \mathrm{ha}^{-1} \mathrm{yr}^{-1}$ ) } \\
\hline 31 & Model GPP & 30.9 & $3.1^{\mathrm{b}}$ & 26.9 & $2.7^{\mathrm{b}}$ & 2002, Fisher et al. (2007) \\
\hline 32 & Model GPP & 31.4 & $3.1^{\mathrm{b}}$ & 27.1 & $2.7^{\mathrm{b}}$ & 2003, Fisher et al. (2007) \\
\hline 33 & Eddy covariance GPP & 36.3 & - & - & - & Carswell et al. (2002) \\
\hline 34 & Component $R_{\text {soil }}$ & 16.3 & - & 12.1 & - & Sotta et al. (2007) \\
\hline 35 & Model $R_{\text {soil }}$ & 11.7 & - & 9.5 & - & Malhi et al. (2009b) \\
\hline 36 & Model TBCA & 6.0 & 0.9 & 7.0 & 1.1 & Raich \& Nadelhoffer (1989) \\
\hline
\end{tabular}

Given the unreplicated nature of the plots, error bars represent only within-plot spatial variation and measurement error rather than landscape-scale heterogeneity. Values in source calculations refer to the parameter identity numbers (first column).

TFE, through-fall exclusion; DBH, diameter at breast height; PCE, plant carbon expenditure; TBCA, total below-ground carbon (C) allocation from the method of Raich \& Nadelhoffer (1989) modified to include the contributions of coarse branches, root litter and dissolved organic carbon (DOC); CUE, carbon use efficiency; $R_{\text {ecor }}$ ecosystem respiration; $R_{\text {autor }}$ autotrophic respiration; $R_{\text {hetero, }}$, heterotrophic respiration; $R_{\text {soil, }}$ soil $\mathrm{CO}_{2}$ efflux.

${ }^{a}$ NTP, net tree production, is the balance between $C$ entering and exiting live plant biomass.

${ }^{b} 10 \%$ of gross primary productivity (GPP), derived from Fox et al. (2009). Alternative ecosystem level C fluxes are separated into three broad sources: modelled data, eddy covariance data and 'component' data from component-scale field measurements.

in the TFE plot do indeed have lower NSC contents relative to trees in the control.

\section{Drought effects on carbon partitioning and turnover}

In the TFE plot there was a large decrease in plant $\mathrm{C}$ stocks, particularly below ground, attributable to an elevated rate of tree mortality relative to the control (Fig. 5; da Costa et al., 2010). Estimated plant C stocks situated below ground constituted $24 \pm 8$ and $8 \pm 3 \%$ of the total in the control and TFE plots, respectively (Fig. 5), compared with global and regional syntheses suggesting a value of around 21\% for tropical forests (Jackson et al., 1996; Cairns et al., 1997). 


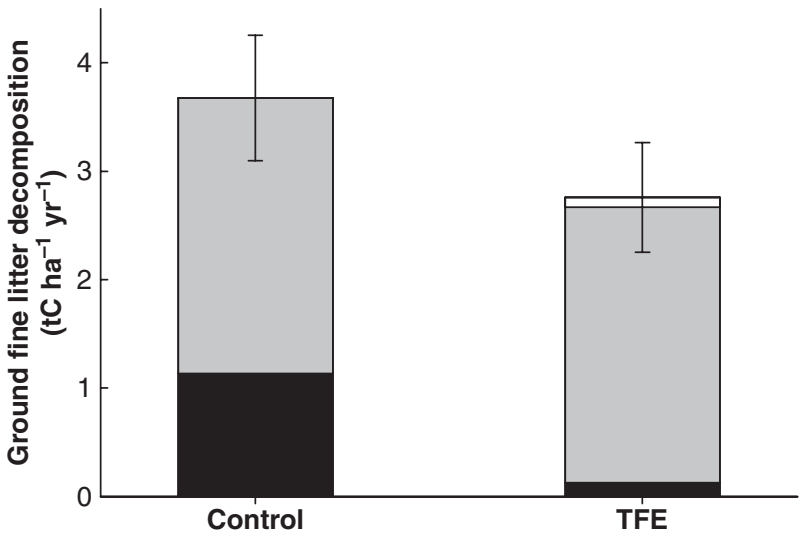

Fig. 7 Contribution of microbial respiration (closed bars) and other processes (grey bars) to decomposition of ground fine litter. Other processes could include physical disintegration and/or consumption by detritivores. Shortfall (S, open bars) represents the imbalance between litter inputs $(L)$ and decomposition required to account for the observed increases in fine litter stock in the through-fall exclusion (TFE) plot relative to the control, assuming that there was no difference in stocks between plots before the TFE treatment. Microbial respiration $(M)$ was estimated by measurement of soil $\mathrm{CO}_{2}$ efflux $\left(R_{\text {soil }}\right)$ at the same point with and without surface litter (Metcalfe et al., 2007a); physical/macrofaunal removal in the plots was calculated as $L-M-S$. Error bars indicate $95 \%$ confidence intervals around the total values. Given the unreplicated nature of the plots, error bars represent only within-plot spatial variation and measurement error rather than landscape-scale heterogeneity.

The relatively modest NPP reduction on the TFE plot is surprising, particularly given the substantial decline in live plant biomass. The two largest components of NPP - stem and canopy production - are also the most reliably measured, and bear out the general conclusion that NPP declined, though not by much, in the TFE plot compared with the control (da Silva et al., 2009; da Costa et al., 2010). While large trees $(>20 \mathrm{~cm} \mathrm{DBH})$ showed substantial reductions in NPP, it was clear, from studies both at this site (da Costa et al., 2010) and another TFE experiment in the Amazon (Brando et al., 2008), that smaller trees $(<20 \mathrm{~cm}$ $\mathrm{DBH})$ appeared to be relatively resilient to drought. This could indicate that understorey trees benefited from increased light availability as the canopy thinned, and/or subcanopy conditions (less wind, higher air humidity and $\mathrm{CO}_{2}$ concentrations) which promoted water-use efficiency.

Plant $R$ responses reported in this study are surprising because drought almost always inhibits $R$ in actively growing plant tissues (Atkin \& Macherel, 2009 and references therein). However, perhaps of significance for this study, responses from slow-growing, mature plants appear to be more variable. This study therefore adds to the minority of documented occurrences of drought-induced increases in plant $R$ (Zagdanska, 1995; Ghashghaie et al., 2001; Bartoli et al., 2005). Other studies in the Amazon have reported dry-season increases in leaf dark $R$ at a standardized temperature (Domingues et al., 2005; Miranda et al., 2005), and a survey of 208 woody plant species from 20, mainly temperate, sites indicated that mean leaf dark $R$ increased as site annual rainfall declined (Wright et al., 2006). Possible physiological mechanisms for drought-induced leaf dark $R$ increase include greater energy demand for maintenance of vacuolar solute gradients, repair of water-stress-induced cell damage and/or increased wastage respiration via futile cycles (Hue, 1982; Lambers, 1997; Lambers et al., 1998; Cannell \& Thornley, 2000; Flexas et al., 2005; Würth et al., 2005; Wright et al., 2006; Atkin \& Macherel, 2009). Relatively less work has been conducted on the underlying mechanisms controlling $R$ from other plant tissues but at least some of the same processes could be operating. Further work is required to explore how consistent these plant $R$ responses to drought are across the Amazon and other mature tropical forests.

The considerable additional respiratory cost imposed on plants by the TFE treatment meant the estimated proportion of PCE used to construct plant tissue (CUE) was $0.24 \pm 0.04$, compared with $0.32 \pm 0.04$ in the control (Table 2, Fig. 4). Estimated CUE of the control plot adds to a growing body of evidence indicating that tropical forests generally have higher respiratory costs relative to tissue growth and therefore a lower CUE, of $c .0 .3$ (Chambers et al., 2004; Malhi et al., 2009b) compared with values usually between 0.4 and 0.6 for boreal and temperate forests (DeLucia et al., 2007). To accurately simulate current and future forest $\mathrm{C}$ cycling, it may be important to incorporate these physiological responses into current models, many of which assume constant CUE over space and time (e.g. Hyland, Levy et al., 2004; 3PG, Landsberg \& Waring, 1997; CASA, Potter et al., 1993; Forest-BGC, Running \& Coughlan, 1988). In addition, further work is required to collect similar data at more tropical forest sites to explore the generality of this pattern.

The 'functional balance' theory suggests that plants might respond to the TFE treatment by shifting partitioning of $C$ towards roots, at the expense of other tissues, where photosynthate can be used to increase water uptake (Thornley, 1972; Cannell \& Dewar, 1994). Our data provide no clear support for this theory: the proportions of total NPP invested in roots and foliage slightly declined in the TFE plot compared with the control (although these mean plot differences were well within 95\% confidence intervals) (Table 2, Fig. 3a). The lack of a clear NPP allocation response could indicate that the forest is adapting to drought in other ways, such as increasing water uptake per unit root mass by increasing specific root length and specific root area (Metcalfe et al., 2008), or that other processes are dominant, such as drought-associated shifts in root turgor pressure and/or soil density, which impede the development of root systems irrespective of plant allocation patterns (Whalley et al., 1998; Bingham \& Bengough, 2003; Bengough et al., 2006). Quantifying partitioning as total forest $\mathrm{C}$ expenditure $\left(\mathrm{NPP}+R_{\text {auto }}\right)$ provides another test of the functional 
(a)

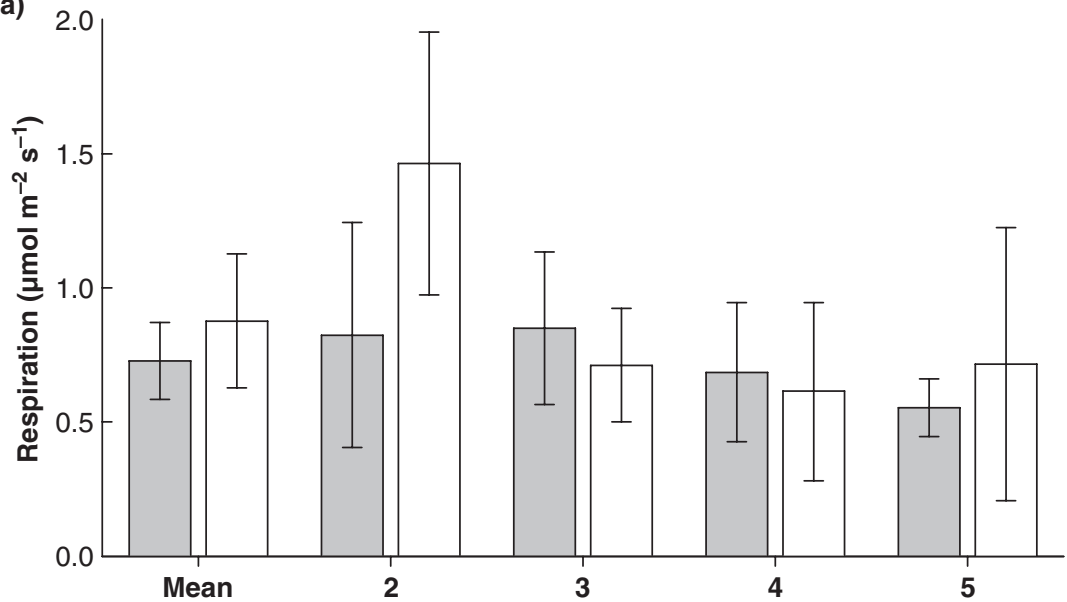

(b)

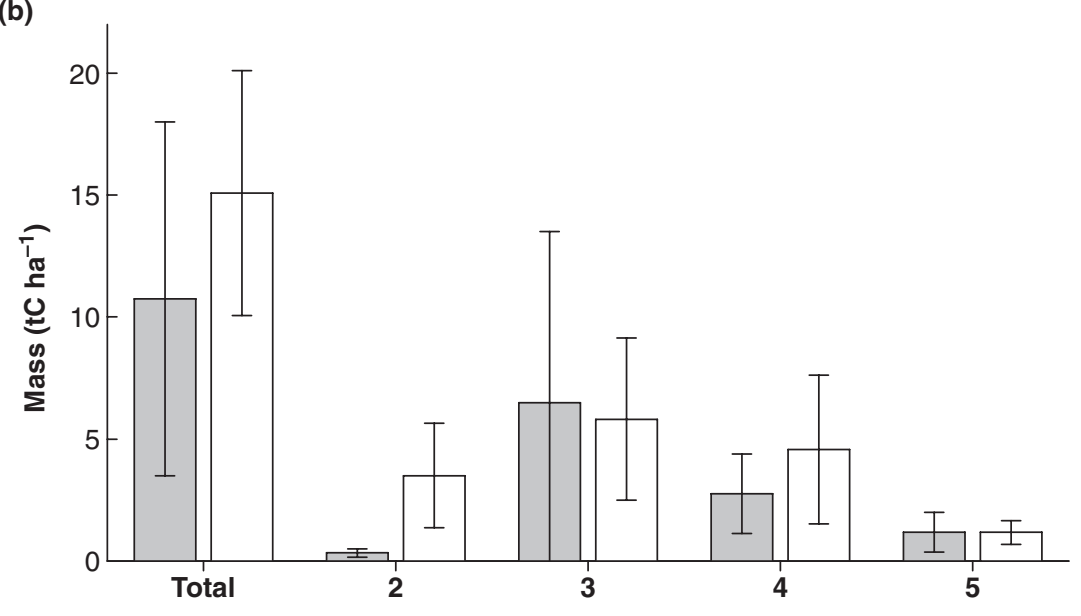

Fig. 8 Coarse woody debris (CWD) respiration (a) and carbon stocks (b) in both plots. Grey bars, control; open bars, through-fall exclusion (TFE). Error bars indicate $95 \%$ confidence intervals around the values. CWD stocks were measured in 2009 and back-calculated to 2005 assuming dead stem and CWD stock accumulation was proportional to measured tree mortality. Given the unreplicated nature of the plots, error bars represent only within-plot spatial variation and measurement error rather than landscape-scale heterogeneity. Values indicate means/totals for the entire plot and are divided into the following four decomposition categories following Harmon et al. (1995): 2, firm wood with bark intact but no leaves or fine twigs; 3 , firm wood with rotten/sloughing bark; 4 , partially rotten wood which can be broken when kicked; 5 , completely rotten wood which can be broken apart by hand. balance theory, and reveals a different pattern to that of NPP alone. The decline in NPP in the TFE plot was offset by a substantial estimated rise in canopy $R$, with the net effect that total C partitioning to both roots and canopy apparently increased in the TFE plot relative to the control, although, again, this trend should be interpreted with caution given the substantial uncertainties around the means (Table 2).

da Costa et al. (2010) estimate that increased stem mortality in the TFE plot produced c. $33 \mathrm{t} \mathrm{C} \mathrm{ha}^{-1}$ more dead woody material than in the control over the $7 \mathrm{yr}$ from 2002 to 2008. It might be expected that this necromass would decompose relatively slowly under the drier conditions in the TFE plot, but in this study we observed no clear inhibition of CWD respiration on the TFE treatment (Fig. 8a). Thus, if there was any difference in amounts of CWD moisture between plots, this appeared to have little effect on microbial activity on the CWD surface. $R$ per unit wood surface appears to have remained similar between plots, whilst the total quantity of dead wood dramatically increased in the TFE plot (Fig. 1; da Costa et al., 2010), with the result that stand-level dead wood $R$ was greater in the TFE plot than in the control (Table 2). There was also a weak trend towards higher $R$ from fresh wood material in both plots (Fig. 8a), perhaps because more labile $\mathrm{C}$ was accessible to microbes on the surface of the wood, and there were greater quantities of fresh wood in the TFE plot (Fig. 8b), which further contributed to increased CWD emissions in the TFE plot relative to the control (Table 2, Fig. 3b). By contrast, fine litter $R$ was approximately 10 times lower in the TFE plot than in the control (Table 2), but the measured increase in fine litter $\mathrm{C}$ stocks in the TFE plot was relatively minor (Table 1). Taken together, this suggests that other decomposition processes, such as physical disintegration and consumption by detritivores, became more important in the TFE plot (Fig. 7). The shifts in $R_{\text {hetero }}$ observed in this study may have important consequences for turnover of $\mathrm{C}$ stocks which, together with TFEinduced changes in $\mathrm{C}$ stocks, could translate into important changes in ecosystem $\mathrm{CO}_{2}$ emissions.

\section{Method validation and intercomparison}

This study has compiled all available site data and, where necessary, taken values from other Amazon forests to 
construct a detailed snapshot of estimated C fluxes in the fourth year of a drought experiment in eastern Amazonia. Analyses of longer-term change of some components and more detailed work focused on individual components may be found elsewhere (Nepstad et al., 2002; Davidson et al., 2004, 2008; Sotta et al., 2007; Metcalfe et al., 2007a, 2008, 2010; Brando et al., 2008; Meir et al., 2008; da Silva et al., 2009; Meir et al., 2009; da Costa et al., 2010). The 'bottom-up' approach used in this study to estimate PCE and $R_{\text {eco }}$ in the control plot showed a reasonable degree of consistency with earlier estimates of stand-level C fluxes at this site made using both eddy covariance and modelling methods (Table 2). However, from the equations which estimate $R_{\text {soil }}$ (Malhi et al., 2009b) and TBCA (Raich \& Nadelhoffer, 1989) from above- and below-ground C inputs, there is an indication that there is higher measured $R_{\text {soil }}$ and TBCA than expected (Table 2), which could indicate insufficient field sampling or that further work is required to parameterize the mass balance models. Eddy covariance studies in central/eastern Amazon terra firme old-growth forest have recorded very different rates of annual ecosystem $\mathrm{C}$ uptake and release, with distinct seasonal patterns (Saleska et al., 2003; Ometto et al., 2005). Bottom-up measurements could help to specify which components of $R_{\text {eco }}$ (e.g. $R_{\text {auto }}$ vs $R_{\text {hetero }}$ ) and GPP (e.g. $R$ vs NPP) contribute to explaining the observed differences. This study provides some of the first insights into ecosystem-level shifts in Amazon forest C metabolism associated with drought, which, although constrained by numerous uncertainties, provide a foundation for future modelling and experimental work testing questions and patterns arising from the data presented.

\section{Acknowledgements}

This research contributes to the Brazil-led LBA project and was supported by a NERC PhD studentship and research grant (NER/A/S/2003/1609), a RS Dudley Stamp award, and a University of Edinburgh Elizabeth Sinclair award. Thanks to Leonardo Sá and Ima Vieira for their scientific support and collaboration, and the Museu Paraense Emilio Goeldi for the use of its field station and laboratory facilities.

\section{References}

Aragão LEOC, Malhi Y, Metcalf DB, Silva-Espejo JE, Jiménez E, Navarrete D, Almeida S, da Costa ACL, Salinas N, Phillips OL et al. 2009. Above- and below-ground net primary productivity across ten Amazonian forests on contrasting soils. Biogeosciences 6: 2759-2778.

Atkin OK, Evans JR, Ball MC, Lambers H, Pons TL. 2000. Leaf respiration of snow gum in the light and dark: interactions between temperature and irradiance. Plant Physiology 122: 915-923.
Atkin OK, Macherel D. 2009. The crucial role of plant mitochondria in orchestrating drought tolerance. Annals of Botany 103: 581-597.

Bartoli CG, Gomez F, Gergoff G, Guiamet JJ, Puntarulo S. 2005. Upregulation of the mitochondrial alternative oxidase pathway enhances photosynthetic electron transport under drought conditions. Journal of Experimental Botany 56: 1269-1276.

Bengough AG, Bransby MF, Hans J, McKenna SJ, Roberts TJ, Valentine TA. 2006. Root responses to soil physical conditions; growth dynamics from field to cell. Journal of Experimental Botany 57: 437-447.

Betts RA, Cox PM, Collins M, Harris PP, Huntingford C, Jones CD. 2004. The role of ecosystem-atmosphere interactions in simulated Amazonian precipitation decrease and forest dieback under global climate warming. Theoretical Applied Climatology 78: 157-175.

Bingham IJ, Bengough AG. 2003. Morphological plasticity of wheat and barley roots in response to spatial variation in soil strength. Plant and Soil 250: 273-282.

Brando PM, Nepstad DC, Davidson EA, Trumbore SE, Ray D, Camargo P. 2008. Drought effects on litterfall, wood production, and belowground carbon cycling in an Amazon forest: results of a throughfall reduction experiment. Philosophical Transactions of the Royal Society of London - Biological Sciences 363: 1839-1848.

Cairns MA, Brown S, Helme EH, Baumgardner GA. 1997. Root biomass allocation in the world's upland forests. Oecologia 111: 1-11.

Cannell MGR, Dewar RC. 1994. Carbon allocation in trees: a review of concepts for modelling. Advances in Ecological Research 25: 59-104.

Cannell MGR, Thornley JHM. 2000. Modelling the components of plant respiration: some guiding principles. Annals of Botany 85: 45-54.

do Carmo JB, Keller M, Dias JD, de Camargo PB, Crill P. 2006. A source of methane from upland forests in the Brazilian Amazon. Geophysical Research Letters 33: L04809. doi: 10.1029/2005GL025436.

Carpenter SR. 1996. Microcosm experiments have limited relevance for community and ecosystem ecology. Ecology 77: 677-680.

Carswell FE, Costa AL, Palheta M, Malhi Y, Meir P, de Costa PR, de Ruivo M, do Leal SM, Costa JMN, Clement RJ et al. 2002. Seasonality in $\mathrm{CO}_{2}$ and $\mathrm{H}_{2} \mathrm{O}$ flux at an eastern Amazonian rain forest. Journal of Geophysical Research - Atmospheres 107(D20): 8076. doi: 10.1029/2000JD000284.

Cavaleri MA, Oberhauer SF, Ryan MG. 2006. Wood $\mathrm{CO}_{2}$ efflux in a primary tropical forest. Global Change Biology 12: 2442-2458.

Chambers JQ, dos Santos J, Ribeiro RJ, Higuchi N. 2001. Tree damage, allometric relationships, and above-ground net primary production in central Amazon forest. Forest Ecology and Management 152: 73-84.

Chambers JQ, Higuchi N, Schimel JP, Ferreira LV, Melack JM. 2000. Decomposition and carbon cycling of dead trees in tropical forests of the central Amazon. Oecologia 122: 380-388.

Chambers JQ, Tribuzy ES, Toledo LC, Crispim BF, Higuchi N, Dos Santos J, Araújo AC, Kruijt B, Nobre AD, Trumbore SE. 2004. Respiration from a tropical forest ecosystem: partitioning of sources and low carbon use efficiency. Ecological Applications 14: 72-88.

Christensen JH, Hewitson B, Busuioc A, Chen A, Gao X, Held I, Jones R, Kolli RK, Kwon WT, Laprise R et al. 2007. Regional climate projections. In: Solomon S, Qin D, Manning M, Chen Z, Marquis M, Averyt KB, Tignor M, Miller ML, eds. Climate Change 2007: the physical science basis. Cambridge, UK: Cambridge University Press, 847-940.

Clark DA, Brown S, Kicklighter DW, Chambers JQ, Thomlinson JR, Ni J, Holland EA. 2001. NPP in tropical forests: an evaluation and synthesis of the existing field data. Ecological Applications 11: 371-384.

Collins M, Tett SFB, Cooper C. 2001. The internal climate variability of HadCM3, a version of the Hadley Centre coupled model without flux adjustments. Climate Dynamics 17: 61-81.

da Costa ACL, Braga AP, Goncalves PHL, Da Costa RF, Athaydes Silva JA Jr, Malhi YS, Aragao LEOC, Meir P. 2006. Estudos 
hidrometeorologicos em uma floresta tropical chuvosa na Amazonia Projeto Esecaflor. Revista Brasileira de Meteorologia 21: 283-290.

da Costa ACL, Galbraith D, Almeida S, Portela BTT, da Costa M, de Athaydes Silva Junior J, Braga AP, de Gonçalves PHL, de Oliveira AAR, Fisher $\mathrm{R}$ et al. 2010. Effect of 7 yr of experimental drought on vegetation dynamics and biomass storage of an eastern Amazonian rainforest. New Phytologist 187: 579-591.

Cox PM, Harris PP, Huntingford C, Betts RA, Collins M, Jones CD, Jupp TE, Marengo JA, Nobre CA. 2008. Increasing risk of Amazonian drought due to decreasing aerosol pollution. Nature 453: 212-216.

Davidson EA, Ishida FY, Nepstad DC. 2004. Effects of an experimental drought on soil emissions of carbon dioxide, methane, nitrous oxide, and nitric oxide in a moist tropical forest. Global Change Biology 10: 718-730.

Davidson EA, Nepstad DC, Ishida FY, Brando PM. 2008. Effects of an experimental drought and recovery on soil emissions of carbon dioxide, methane, nitrous oxide, and nitric oxide in a moist tropical forest. Global Change Biology 14: 2582-2590.

DeLucia EH, Drake JE, Thomas RB, Gonzalez-Meler M. 2007. Forest carbon use efficiency: is respiration a constant fraction of gross primary productivity? Global Change Biology 13: 1157-1167.

Domingues TF, Berry JA, Martinelli LA, Ometto JPH, Ehleringer JR. 2005. Parameterization of canopy structure and leaf-level gas exchange for an eastern Amazonian tropical rain forest (Tapajós National Forest, Pará, Brazil). Earth Interactions 9: 1-23.

Edwards PJ. 1977. Studies of mineral cycling in a montane rain forest in New Guinea II. Production and disappearance of litter. Journal of Ecology 65: 971-992.

Fisher RA, Williams M, Lobo do Vale R, da Costa ACL, Meir P. 2006. Evidence from Amazonian forests is consistent with isohydric control of leaf water potential. Plant, Cell \& Environment 29: 151-165.

Fisher RA, Williams M, Lola da Costa A, Malhi Y, da Costa RF, Almeida S, Meir P. 2007. The response of an eastern Amazonian rain forest to drought stress: results and modeling analyses from a throughfall exclusion experiment. Global Change Biology 13: 2361-2378.

Flexas J, Galmes J, Ribas- Carbo M, Medrano H. 2005. The effects of water stress on plant respiration. In: Lambers H, Ribas-Carbo M, eds. Plant respiration: from cell to ecosystem. Dordecht, the Netherlands: Springer, 95-135.

Fox A, Williams M, Richardson AD, Cameron D, Gove JH, Quaife T, Ricciuto D, Reichstein M, Tomelleri E, Trudinger CM et al. 2009. The REFLEX project: comparing different algorithms and implementations for the inversion of a terrestrial ecosystem model against eddy covariance data. Agricultural and Forest Meteorology 149 1597-1615.

Frangi JL, Lugo AE. 1985. Ecosystem dynamics of a subtropical floodplain forest. Ecological Monographs 55: 351-369.

Ghashghaie J, Duranceau M, Badeck FW, Cornic G, Adeline MT, Deleens E. 2001. Delta $\mathrm{C}^{13}$ of $\mathrm{CO}_{2}$ respired in the dark in relation to delta $\mathrm{C}^{13}$ of leaf metabolites: comparison between Nicotiana sylvestris and Helianthus annuus under drought. Plant, Cell \& Environment 24: 505-515.

Graham EA, Mulkey SS, Kitajima K, Phillips NG, Wright SJ. 2003. Cloud cover limits net $\mathrm{CO}_{2}$ uptake and growth of a rainforest tree during tropical rainy seasons. Proceedings of the National Academy of Sciences, USA 100: 572-576.

Harmon ME, Whigham DF, Sexton J, Olmsted I. 1995. Decomposition and mass of dead wood in the dry tropical forests of the northeastern Yucatan Peninsula, Mexico. Biotropica 27: 305-316.

Harris PP, Huntingford C, Cox PM. 2008. Amazon Basin climate under global warming: the role of the sea-surface temperature. Philosophical Transactions of the Royal Society of London - Biological Sciences 363: 1753-1759.
Houghton RA, Lawrence KT, Hackler JL, Brown S. 2001. The spatial distribution of forest biomass in the Brazilian Amazon: a comparison of estimates. Global Change Biology 7: 731-746.

Hue L. 1982. Futile cycles and regulation of metabolism. In: Sies H, ed. Metabolic compartmentation. Burlington, MA, USA: Academic Press, 71-97.

Hurlbert SH. 1984. Pseudoreplication and the design of ecological field experiments. Ecological Monographs 54: 187-211.

Hurlbert SH. 2004. On misinterpretations of pseudoreplication and related matters: a reply to Oksanen. Oikos 104: 591-597.

Jackson RB, Canadell J, Ehleringer JR, Mooney HA, Sala OE, Schulze ED. 1996. A global analysis of root distributions for terrestrial biomes. Oecologia 108: 389-411.

Kuhn U, Andreae MO, Ammann C, Araújo AC, Brancaleoni E, Ciccioli P, Dindorf T, Frattoni M, Gatti LV, Ganzeveld L et al. 2007. Isoprene and monoterpene fluxes from Central Amazonian rainforest inferred from tower-based and airborne measurements, and implications on the atmospheric chemistry and the local carbon budget. Atmospheric Chemistry and Physics 7: 2855-2879.

Lambers H. 1997. Respiration and the alternative oxidase. In: Foyer CH, Quick WP, eds. A molecular approach to primary metabolism in plants. London, UK: Taylor \& Francis, 295-309.

Lambers H, Chapin FS III, Pons TL. 1998. Plant physiological ecology. New York, NY, USA: Springer-Verlag.

Landsberg JJ, Waring RH. 1997. A generalised model of forest productivity using simplified concepts of radiation-use efficiency, carbon balance and partitioning. Forest Ecology and Management 95: 209-228.

Levy PE, Cannell MGR, Friend AD. 2004. Modelling the impact of future changes in 811 climate, $\mathrm{CO}_{2}$ concentration and land use on natural ecosystems and the terrestrial 812 carbon sink. Global Environmental Change 14: 21-30.

Lloyd J, Patino S, Paiva RQ, Nardoto GB, Quesada CA, Santos AJB, Baker TR, Brand WA, Hilke I, Gielmann H et al. 2009. Variations in leaf physiological properties within Amazon forest canopies. Biogeosciences Discussions 6: 4639-4692.

Malhi Y, Aragão LEOC, Galbraith D, Huntingford C, Fisher R, Zelazowski P, Sitch S, McSweeney C, Meir P. 2009a. Exploring the likelihood and mechanism of a climate-change-induced dieback of the Amazon rainforest. Proceedings of the National Academy of Sciences, USA. doi: 10.1073/pnas.0804619106.

Malhi Y, Aragão LEOC, Metcalfe DB, Paiva R, Quesada CA, Almeida S, Anderson L, Brando P, Chambers JQ, da Costa ACL et al. 2009b. Comprehensive assessment of carbon productivity, allocation and storage in three Amazonian forests. Global Change Biology 15: 12551274 .

Malhi Y, Timmons Roberts J, Betts RA, Killeen TJ, Li W, Nobre C. 2008. Climate change, deforestation, and the fate of the Amazon. Science 319: 169-172.

Malhi Y, Wood D, Baker TR, Wright J, Phillips OL, Cochrane T, Meir P, Chave J, Almeida S, Arroyo L et al. 2006. The regional variation of aboveground live biomass in old-growth Amazonian forests. Global Change Biology 12: 1107-1138.

McDowell N, Pockman WT, Allen CD, Breshears DD, Cobb N, Kolb T, Plaut J, Sperry J, West A, Williams DG et al. 2008. Mechanisms of plant survival and mortality during drought: why do some plants survive while others succumb to drought? New Phytologist 178: 719-739.

McDowell N, Sevanto S. 2010. The mechanisms of carbon starvation: how, when, or does it even occur at all? New Phytologist 186: 264-266.

Meir P, Brando PM, Nepstad D, Vasconcelos S, Costa ACL, Davidson E, Almeida S, Fisher RA, Sotta ED, Zarin D et al. 2009. The effects of drought on Amazonian rain forests. In: Keller M, Bustamente M, Gash J, Silva Dias P, eds. Amazonia and global change. Washington, DC, USA: American Geophysical Union Geophysical Monograph Series 186: $429-449$. 
Meir P, Grace J. 2002. Scaling relationships for woody tissue respiration in two tropical forests. Plant, Cell \& Environment 25: 963-973.

Meir P, Metcalfe DB, Costa ACL, Fisher RA. 2008. The fate of assimilated carbon during drought: impacts on respiration in Amazon rainforests. Philosophical Transactions of the Royal Society of London Biological Sciences 363: 1849-1855.

Metcalfe DB, Lobo-do-Vale R, Chaves MM, Maroco JP, Aragão LEOC, Malhi Y, Da Costa AL, Braga A, Gonçalves PL, De Athaydes J et al. 2010. Impacts of experimentally imposed drought on leaf respiration and morphology in an Amazon rainforest. Functional Ecology. doi: 10.1111/j.1365-2435.2009.01683.x

Metcalfe DB, Meir P, Aragão LEOC, Da Costa ACL, Braga AP, Gonçalves PHL, De Athaydes Silva J Jr, de Almeida SS, Dawson LA, Malhi Y et al. 2008. The effects of water availability on root growth and morphology in an Amazon rainforest. Plant and Soil 311: 189-199.

Metcalfe DB, Meir P, Aragão LEOC, Malhi Y, da Costa ACL, Braga A, Gonçalves PHL, de Athaydes J, de Almeida SS, Williams M. 2007a. Factors controlling spatio-temporal variation in carbon dioxide efflux from surface litter, roots, and soil organic matter at four rain forest sites in the eastern Amazon. Journal of Geophysical Research - Biogeosciences 112: G04001. doi: 10.1029/2007JG000443.

Metcalfe DB, Williams M, Aragão LEOC, Da Costa ACL, De Almeida SS, Braga AP, Gonçalves PHL, De Athaydes Silva J Jr, Malhi Y, Meir P. 2007b. A method for extracting plant roots from soil which facilitates rapid samples processing without compromising measurement accuracy. New Phytologist 174: 697-703.

Miranda EJ, Vourlitis GL, Filho NP, Priante PC, Campelo JH, Suli GS, Fritzen CL, De Almeida Lobo F, Shiraiwa S. 2005. Seasonal variation in the leaf gas exchange of tropical forest trees in the rain forest- savanna transition of the southern Amazon basin. Journal of Tropical Ecology 21: 451-460.

Nepstad DC, Moutinho P, Dias MB, Davidson E, Cardinot G, Markewitz D, Figueiredo R, Vianna N, Chambers J, Ray D et al. 2002. The effects of partial throughfall exclusion on canopy processes, aboveground production and biogeochemistry of an Amazon forest. Journal of Geophysical Research - Atmospheres 107: 1-18.

Ometto JPHB, Nobre AD, Rocha HR, Artaxo P, Martinelli LA. 2005. Amazonia and the modern carbon cycle: lessons learned. Oecologia 143: 483-500.

Osmond B, Ananyev G, Berry J, Langdon C, Kolber Z, Lin G, Monson R, Nichol C, Rascher U, Schurr U et al. 2004. Changing the way we think about global change research: scaling up in experimental ecosystem science. Global Change Biology 10: 393-407.

Penning de Vries FWT. 1975. The cost of maintenance processes in plant cells. Annals of Botany 39: 77-92.

Peylin P, Bousquet P, le Quéré C, Sitch S, Friedlingstein P, McKinley G, Gruber N, Rayner P, Ciais P 2005. Multiple constraints on regional $\mathrm{CO}_{2}$ flux variations over land and oceans. Global Biogeochemical Cycles 19: GB1011. doi: 10.1029/2003GB002214.

Poorter L, Kitajima K. 2007. Carbohydrate storage and light requirements of tropical moist and dry forest tree species. Ecology 88: $1000-1011$.

Potter CS, Randerson JT, Field CB, Matson PA, Vitousek PM, Mooney HA, Klooster SA. 1993. Terrestrial ecosystem production: a process model based on global satellite and surface data. Global Biogeochemical Cycles 7: 811-841.

Quesada CA, Lloyd J, Anderson LO, Fyllas NM, Schwarz M, Czimczik CI. 2009. Soils of amazonia with particular reference to the rainfor sites. Biogeosciences 6: 3851-3921.

Raich JW, Nadelhoffer KJ. 1989. Below-ground carbon allocation in forest ecosystems global trends. Ecology 70: 1346-1354.

Running SW, Coughlan JC. 1988. A general-model of forest ecosystem processes for regional applications: I. Hydrologic balance, canopy gas-exchange and primary production processes. Ecological Modelling 42: $125-154$.

Saatchi SS, Houghton RA, Dos Santos Alvala RC, Soares JV, Yu Y. 2007. Distribution of aboveground live biomass in the Amazon basin. Global Change Biology 13: 816-837.

Sala A, Piper F, Hoch G. 2010. Physiological mechanisms of droughtinduced tree mortality are far from being resolved. New Phytologist 186: 274-281.

Saleska SR, Miller SD, Matross DM, Goulden ML, Wofsy SC, da Rocha HR, de Camargo PB, Crill P, Daube BC, de Freitas HC et al. 2003. Carbon in Amazon forests: unexpected seasonal fluxes and disturbanceinduced losses. Science 302: 1554-1557.

da Silva RM, da Costa JMN, Ruivo MDLP, da Costa ACL, Almeida SS. 2009. Influência de variáveis meteorológicas na produção de liteira na Estação Científica Ferreira Penna, Caxiuanã, Pará. Acta Amazonica 39: 573-582.

Silver W, Neff JC, McGroddy M, Veldkamp E, Keller M, Oliveira RC Jr. 2000. Effects of soil texture on belowground carbon and nutrient storage in a lowland Amazonian forest ecosystem. Ecosystems 3: 193209.

Sotta ED, Veldkamp E, Schwendenmann L, Guimarães BR, Paixão RK, Ruivo MLP, da Costa ACL, Meir P. 2007. Effects of an induced drought on soil carbon dioxide $\left(\mathrm{CO}_{2}\right)$ efflux and soil $\mathrm{CO}_{2}$ production in an eastern Amazonian rainforest, Brazil. Global Change Biology 13: 2218-2229.

Stokstad E. 2005. Experimental drought predicts grim future for rainforest. Science 308: 346-347.

Sullivan TJ. 1997. Ecosystem manipulation experimentation as a means of testing a biogeochemical model. Environmental Management 21: 15-21.

Thornley JHM. 1972. A balanced quantitative model for root : shoot ratios in vegetative plants. Annals of Botany 36: 431-441.

Tian H, Melillo JM, Kicklighter DW, McGuire AD, Helfrich J, Moore B III, Vörösmarty CJ. 1998. Effect of interannual climate variability on carbon storage in Amazonian ecosystems. Nature 396: 664-667.

Waterloo MJ, Oliveira SM, Drucker DP, Nobre AD, Cuartas LA, Hodnett MG, Langedijk I, Jans WWP, Tomasella J, de Araújo AC et al. 2006. Export of organic carbon in run-off from an Amazonian rainforest blackwater catchment. Hydrological Processes 20: 2581-2597.

Werth D, Avissar R. 2002. The local and global effects of Amazon deforestation. Journal of Geophysical Research 107: 8087. doi: 10.1029/ 2001/JD000717.

Whalley WR, Bengough AG, Dexter AR. 1998. Water stress induced by PEG decreases the maximum growth pressure of the roots of pea seedlings. Journal of Experimental Botany 49: 1689-1694.

Wright IJ, Reich PB, Atkin OK, Lusk CH, Tjoelker MG, Westoby M. 2006. Irradiance, temperature and rainfall influence leaf dark respiration in woody plants: evidence from comparisons across 20 sites. New Phytologist 169: 309-319.

Würth MKR, Pelaez-Riedl S, Wright SJ, Körner C. 2005. Non-structural carbohydrate pools in a tropical forest. Oecologia 143: 11-24.

Yoda K. 1983. Community respiration in a lowland rain forest in Pasoh, peninsular Malaysia. Japanese Journal of Ecology 33: 183-197.

Yoneda T. 1993. Surface area of woody organs of an evergreen broadleaf forest tree in Japan, southeast Asia. Journal of Plant Research 106: 229237.

Zagdanska B. 1995. Respiratory energy demand for protein turnover and ion transport in wheat leaves upon water deficit. Physiologia Plantarum 95: 428-436.

Zeng N, Mariotti A, Wetzel P 2005. Terrestrial mechanisms of interannual $\mathrm{CO}_{2}$ variability. Global Biogeochemical Cycles 19: GB1016. doi: $10.1029 / 2004 \mathrm{~GB} 002273$. 